\title{
OBjeTOS RITUALES
}

Por:

Jaime Ruiz Solórzano

Magister en Historia

Docente Departamento de Artes

Facultad de Educación

Universidad Surcolombiana

\section{Resumen:}

El presente artículo es un texto crítico sobre la obra de Martha Eugenia Pachón Rodríguez, egresada del programa de Artes Visuales de la Universidad Surcolombiana, quien actualmente reside y desarrolla su trabajo creativo en Italia. Este texto inicialmente fue publicado en Faenza con traducción al italiano y al inglés por Emma Suñol y Romana Malbasa, respectivamente. ${ }^{1}$ Se incluye aquí con el fin de explicar las imágenes contenidas en esta edición de la revista Paidea Surcolombiana y, simultáneamente, divulgar la obra de esta artista de nuestra Región.

El texto aborda en orden secuencial: una breve memoria de sus actividades y características personales como estudiante; la aproximación al trasfondo cultural de sus obras; un rastreo de las tradiciones artísticas que ha influenciado su lenguaje creativo; la síntesis del proceso de creación; la interpretación de imágenes metafóricas a partir del análisis de las forma y el contenido.

\section{Palabras clave:}

Cerámica; Tradiciones artísticas; Proceso de creación; Forma; Contenido. 
$\mathrm{L}^{2}$ a ceramista Martha Pachón (M. P.) es oriunda de Bogotá, capital de la República de Colombia en el continente Latinoamericano; pero su formación la realizó en el Huila, Departamento ubicado al sur de su país. Respecto el tiempo de su formación en la Universidad Surcolombiana, corren por mi mentes tres instantáneas fugaces: inicialmente le veo realizando lo primeros balbuceos en los talleres de dibujo y modelado con arcilla; luego, participando activamente en las clases de historia del arte, donde inventó e impulsó el montaje de «ambientaciones» con el fin de crear un clima propicio para el análisis y el debate de los tópicos de estudio; un tercer momento escuchando los reconocimientos recibidos por su obra, que a gritos comenzó a reclamar nuevos contextos para su desarrollo.

Junto a ello siempre la acompaño el inconformismo, la asunción con valentía de todos los retos, la cultura del trabajo y la terquedad creativa; características que la llevaron a la situación, que en el ámbito artístico denominamos, «transterritorializada», para el caso en Italia $y$ con sus valiosas personas que la han acogido con generosidad.

Es claro que M. P. representa en su ser el conocido "mestizaje étnico cultural», esa humanidad acrisolada en el «Nuevo Mundo», que el pensador mexicano José Vasconcelos denominara en 1925 «la Raza Cósmica»², fruto de la mezcla de pueblos precolombinos, españoles, negros fusionados a partir a partir del siglo XVI y posteriormente complementada con el advenimiento de asiáticos, en menor cantidad. En los herederos de tal mestizaje le es propia su apertura mental a todas las culturas, despojada de prejuicios, hecho que les posibilita apropiarse con rapidez de las culturas alternas, sus valores, formas de pensamiento y expresión, con altas posibilidades de transformación enriquecida.

Nuestra artista, por lo tanto, es heredera de grandes tradiciones: primero, el legado de la cerámica precolombina iniciada hacia el 3.100 a. C. ${ }^{3}$, luego perfeccionada a nivel de variedad formal y dominio técnico a través del Período Formativo en sus distintas fases entre el 1.200 a.C. y el siglo XVI por las culturas San Agustín, Terradentro, Tumaco, Calima, Quimbaya, Pastos Quillacinga, Tolima, Sinú, Muisca y Tirona. Segundo, como persona formada en el Departamento del Huila tiene la impronta de los escultures líticos Agustinianos y los ceramistas de la Cultura Santa Ana. Tercero, los conquistadores ibéricos legaron sus grandes imaginarios, pues a nuestras tierras vinieron a buscar: los dorados, las amazonas, las fuentes de la eterna juventud, los paraísos perdidos y luego el rico barroquismo, que imperó durante el dominio colonial entre los siglos XVI y principios del XIX. Cuarto, las enseñanzas más significativas del arte contemporáneo abstracto geométrico, como los planteamientos de Pevsner, Naum Gabo, Constantin Brancusi, Henry Moore e Isamu Noguchi y, de especial manera, escultores colombianos tan importantes como Edgar Negret y Eduardo Ramírez Villamizar, entre muchos otros, que han estudiado la tradición artística de los aborígenes precolombinos para ser interpretados en sus obras.

En este horizonte de creación y rica tradición podemos inscribir la obra de M.P.; pero dejemos que sea le propia ceramista quien nos hable de su proceso de creación: "Generalmente las ideas saltan a la mente con solo recordar mi infancia (cuando 
recolectaba piedras y objetos extraños de los ríos con mi padre, quien me enseño a apreciarlas como objetos mágicos), también con recordar los objetos y formas de la naturaleza que me rodeaban en Colombia, es tanta la riqueza de nuestra cultura, y sobre todo si se tiene en cuenta que tengo conexiones afro caribeñas y andinas que cualquier objeto que me rodeaba me inspira; cuando viene la idea la consigno siempre en papel, luego por días, semanas, meses y hasta años (como sucedió con los mantos rituales que comencé en Colombia 7 años atrás) sigo madurando la idea y sigo dibujando, anotando los colores, las pastas que utilizare, las texturas me vienen a la mente fácilmente, dibujo muchísimo...ahora con mas intensidad que cuando estaba en Colombia, son tantos los bocetos que tengo...luego escojo y defino formas y materiales a utilizar, esto es importante, pues a menudo utilizo engobes naturales traídos de Colombia y debo contar con tener lo suficiente, pues son colores que no obtendré jamás con las tierras que encuentro en Italia».

Respecto al tipo de material empleado «A mi paso por Italia encontré un grave problema que no tenia en casa, las pastas de aquí son menos evolucionadas que las nuestras y contienen muchas sales que afloran a la superficies durante el secado y después de la cocción persisten, por tanto los engobes bruñidos vienen con horribles alones blancos, cosa que no sucede en América y que aquí se soluciona cubriendo de esmalte, pero como mis piezas no son esmaltadas, tuve que encontrar la forma de desaparecer estas sales de las pastas agregando ciertos productos, por tanto, las pastas que compro o encuentro naturalmente las debo preparar cuidadosamente, antes de trabajar con ellas para lograr un punto similar a las nuestras, además estaba a acostumbrada a pastas más plásticas que no tenían problemas de tensión en el secado y otras cosas más, por lo tanto debo estudiar un poco antes de comenzar a trabajar. Aquí uso las terracotas cocidas entre 980 y 1000 grados y el gres a 1000 o 1100 grados, bajo o subo la temperatura de acuerdo al color y timbre que quiero de la pieza, muchas veces si uso engobes no subo más de 1000 grados pues vienen opacos».

Como técnicas de elaboración «uso el modelado a partir de lastras delgadas, calculando un espesor que no sufrirá fracturas, parto usando moldes y luego una vez estampada la pieza, la moldeo y transformo, después el proceso de terminados, decorando partes a pincel con tierras de aquí o de Colombia decantadas (sigillatas), quedan una gama de colores tierra, también enriquezco con finísimas texturas, el secado es muy lento cada pieza está por días y semanas en una habitación concierto grado de humedad, jamás al viento o sol, ya que son muchas veces con paredes que varían de $1 \mathrm{~cm}$ a $2 \mathrm{~cm}$ o de $5 \mathrm{~mm}$, 3mm a $1 \mathrm{~cm}$ por tanto, se pueden producir tensiones y después grietas durante un brusco secado, cuando se encuentra seca completamente, la llevo a monocotura, ya que los colores (engobes o tierras son colocados en estado de punto de cuero, cruda, eso sí, bruñidos pacientemente, hasta conseguir una superficie lisa y lucida), algunas veces después de la primera cocción, debo hacer dos más para el oro de tercer fuego, una con esmalte en la parte que lleva el oro, a980 grados y la ultima con el oro a 750 grados, todas las piezas tienen pequeños ensambles de otras pieza ya sea en cerámica, fibra o madera, al final las armo y combino todos estos materiales, siempre las 
fibras me las he traído de casa, le dan más calidez y organicidad a la pieza»

Con este trabajo ofrece al mundo sus cerámicas como metáforas del modelo de la nube, arriba descrito, así se configura una realidad inconmensurable, como todo gran arte, de una parte lo reconocible y de otra, impregnada de lo aleatorio y la incertidumbre, aquello complejo de descifrar, al lo que solo nos aproximamos por asociaciones, abducciones, intuición y experiencia sensible.

Con lo anterior es apenas obvio que los elementos superficiales de sus cerámicas no sólo impactan nuestras competencias perceptivas $y$ $\mathrm{n} \mathrm{u}$ e s $\mathrm{t} \mathrm{r}$ a racionalidad explicativa. De ello nos hablan los esquemas geométricos, 1

\section{a} reiteración de concavidad convexidad, el rehundimiento de planos, las calidades de color, textura y brillo, composiciones imprevistas, inclusiones de materiales y fibras naturales. Todo lo anterior contenido en formas envolventes tridimensionales factibles de asociar a semillas, bastones de poder mágico y autoridad, mantos sagrados, instrumentos de adoración, embarcaciones misteriosas. Aquí la constante común es la dialéctica del espacio externo y interno, la oquedad, la matriz germinal, el secreto, el silencio profundo. 4
Más allá implica efectuar una entrada en la profundidad de su contenido, donde aún susurra el mundo mágico-mítico ancestral. El cual en nuestro bagaje cultural occidental leemos como símbolos y prácticas ignotos; posiblemente relacionados con fuerzas personificadas con elementos astrales: sol, luna, estrellas, pos ic iones cósmicas;

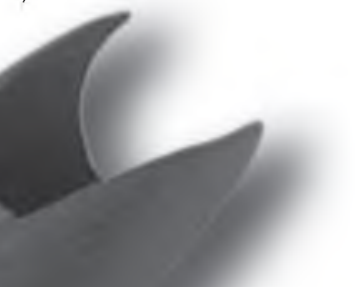

$$
\text { elementos }
$$
naturales: agua, aire, fuego, tierra; fenómenos de la naturaleza: descargas eléctricas, vendavales, lluvias torrenciales; fauna mítica: jaguar, águila, serpiente, peces, saurios, batracios; como dispositivos que en rituales o viajes shamánicos son mediatizados para controlar la naturaleza, los seres, y propiciar soluciones antes situaciones límite.

Por estas razones M. P. a fuerza de reflexión, metamorfosis de formas y conceptos, crea obras innovadoras, generadas de su experticia, o sea experiencia mas conocimiento. Para ello se vale de situar por medio de un proceso deconstrucciónconstrucción las propuestas artísticas ya dadas, de revisar los marcos elementales del pensamiento y el paradigma estético, de desafiar al intelecto y la sensibilidad, de ampliar los referentes artísticos, de imbricar tradición y modernidad, pasado y presente, periferia y centro; para concretar cerámicas 
síntesis como expresión de una cultura glocal, es decir local-global, de un mundo íntimo y a la vez universal. Pero sobre todo propone una obra portadora de imprevisibles trasmutaciones dentro de su connotada hibridez y un dialogo altamente fecundo.

\section{NOTAS}

(1) RUIZ SOLÓRZANO, Jaime. «OBJETOS RITUALES», Catálogo exposición MUSEO INTERNAZIONALE DELLE CERAMICHE IN FAENZA. Faenza, Ed. Circolo Degli Artisti, 29 noviembre 2003-11 enero 2004, pág. 15-25.

(2) VASCONCELOS, José. La Raza Cósmica . México, Ed. Espasa-Calpe, 1976. (N. E. publicado por primera vez en 1925)

(3) CHAVES MENDOZA, Álvaro. Panorama Prehistórico de la Costa Caribe Colombiana - Bogotá, Ed. Universitas HumanísticaUniversidad Javeriana, 1979, p.15

(4) BACHELAR, Gastón. La Poética del Espacio. Bogotá, Ed. FCE, 1994. 


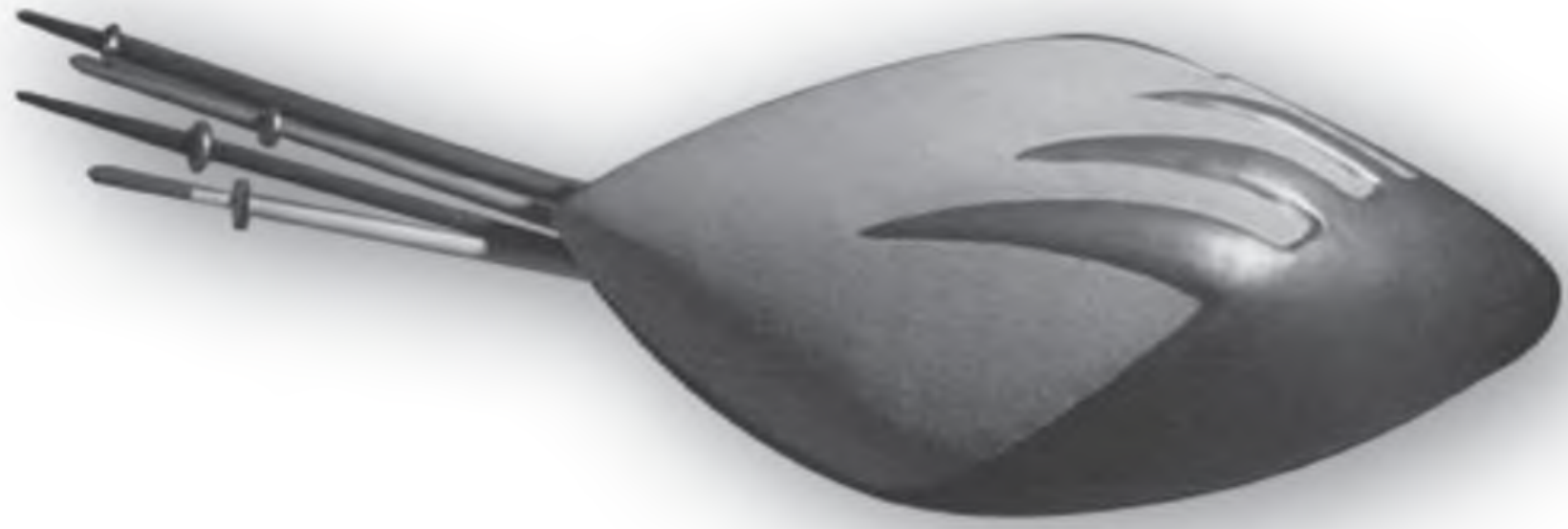

